\title{
THE STRUGGLE OF ISLAM AND CHRISTIANITY IN THE ESTABLISHMENT OF EDUCATIONAL INSTITUTIONS IN BOLAANG MONGONDOW, NORTH SULAWESI (1905-1942)
}

Sabil Mokodenseho and Arif Zamhari

Universitas Islam Negeri Syarif Hidayatullah Jakarta, Indonesia

E-mail: sabil.mokodenseho@gmail.com

\section{Abstract}

This study was conducted due to the scholars' lack of attention in revealing the conditions of education in Bolaang Mongondow in the early twentieth century. Using historical methods, as well as sociological, religious, and political approaches, this study finds that in the early twentieth century, indigenous people received education through the Sarekat Islam's Islamic Education and Teaching Center and the Zending educational institution founded by Christian missionaries. Zending education for indigenous Muslim communities was a form of knowledge discrimination because education was only specifically for Christian children, European descent, and aristocrats, while indigenous Muslim children were not allowed. In contrast, Islamic educational institutions were established to accommodate all Muslim children. As a result, although Islamic education institutions existed long after the Zending educational institutions, their educational institutions can compete. Zending's education ended with the fall of Dutch rule, while Islamic educational institutions continue to exist to date. The differences between the two religions in managing educational institutions lead this paper to the conclusion that religion is important not only in responding to and positioning oneself in power relations but also in empowering individuals and groups. 
Kajian ini dilakukan karena minimnya perhatian para sarjana dalam mengungkap kondisi pendidikan di Bolaang Mongondow awal abad ke-20. Dengan menggunakan metode sejarah, serta pendekatan sosiologi, keagamaan dan politik, kajian ini menemukan bahwa di awal abad ke-20, masyarakat pribumi mendapatkan pendidikan melalui Balai Pendidikan dan Pengajaran Islamiyah milik Sarekat Islam dan lembaga pendidikan Zending yang didirikan misionaris Kristen. Pendidikan Zending bagi masyarakat Muslim pribumi adalah bentuk diskriminasi pengetahuan sebab pendidikannya hanya dikhususkan bagi anak-anak Kristen, keturunan Eropa dan bangsawan, sedangkan anak Muslim pribumi tidak. Berbeda dengan lembaga pendidikan Kristen, lembaga pendidikan Islam didirikan untuk mengakomodir seluruh anak Muslim. Alhasil, meskipun lembaga pendidikan Islam hadir jauh setelah lembaga pendidikan Zending, namun lembaga pendidikannya mampu bersaing. Pendidikan Zending berakhir seiring dengan jatuhnya kekuasaan Belanda, sedangkan lembaga pendidikan Islam terus eksis hingga sekarang. Perbedaan kedua agama tersebut dalam mengelola lembaga pendidikan mengantarkan tulisan ini pada kesimpulan bahwa agama penting bukan hanya soal menanggapi dan memposisikan diri sendiri dalam hubungan kekuasaan, tetapi juga dalam pemberdayaan individu dan kelompok.

Keywords: Bolaang Mongondow; Christian; Formal Educational Institution; Islam; Struggle

Received: March 23, 2021; Accepted: April 26, 2021

\section{Introduction}

The study of Islam and Christianity is still an interesting area to work on because there is a kind of mutual prejudice and suspicion that gradually develops between the two (Wheeler 2020; Mroz 2019; Howard 2016). In the Indonesian context, Arifianto (2009) states the origin of tensions between the two originating from the Dutch colonial period and continuing to survive post-independence Indonesia.

Meanwhile, in the context of Bolaang Mongondow, the encounter between Islam and Christianity had been going on for a long time since the Dutch entered the region. This encounter resulted in tension and competition in various fields, including education. Bolaang Mongondow as an administrative area of onderafdeeling from the residency of Manado consisting of five kingdoms (Rhijn 1941, 267) as well as the assignment of 
controllers and assistant controllers since 1901 implemented the principle of deconcentration (Damopolii 1984, 19). The presence of the Netherlands received a negative response from the indigenous Muslim community because the educational policy for Muslims was discriminated. This response could be understood because, before the arrival of the Dutch, the majority of people had embraced Islam (Kosel 2010; Jansen 1857; Riedel 1864; Ulfers 1868; Clercq 1883) while Christianity had only entered around 1904-1905 since Christian missionaries spread their mission (Suwondo 1978, 102). Among other forms of discrimination, the Netherlands provided differences in the payment of school fees. The school fees for indigenous children were twice as high as the tuition fees for European childresn so that only children of noble and wealthy descent could go to school (Scherer 1985, 44).

During the reign of the Dutch East Indies, two school models were founded, namely Gouvernement Scholen (Government School) and Particuliere Scholen (Private school) (Ter Avest and Rietveld-van Wingerden 2017). Private schools were divided into subsidized schools by the government and non-subsidized private schools. Subsidized private schools were established and maintained by an association that had been recognized by the government and given rights of rechtspersoon (legal entity), or were established and maintained by an association that was outside the land of the Dutch East Indies but had branches in the Dutch East Indies (Mokodenseho 2020, 7). Generally, subsidized private schools were schools established by churches, both Catholic and Protestant. In contrast, only a small amount of subsidies was provided to Islamic schools. As an illustration, in the period 1938-1939, the government gave subsidies to 2016 Protestant schools, 728 Catholic schools, and only a few to Islam i.e. around 113 schools (Algemeen Verslag 1941).

The above matters cannot be separated from ethical-political policies in the field of education. Since 1882, the Netherlands created a special body to control religious life and Islamic education called Priesterraden (Koenig 2020; Van Huis 2019; Roff 2010). It was through this agency's instructions that later in the year 1905, the Netherlands in controlling Islamic education issued a policy, namely the Teacher Ordinance (Suwignyo 2013). All teachers in Islamic schools must obtain a teaching license as in 1932-1933. The Netherlands issued a Wild School Ordinance policy (Wilde School Ordonantie) and dismissed schools that did not have license. 
The change in the goal of ethical politics towards not benefiting the Muslim community was in line with Shihab's (1998, 43-44) view that ethical politics was the framework in which the strengthening of Christianity in Indonesia was established. This policy indicated that there was no neutrality in religion, and had even created socio-cultural changes (Burhanudin 2017). The Dutch government's discrimination against Islam and Islamic education made this function taken over and casrried out by educated people under an organization labelled Islam. Educated people who cared about the condition of the nation formed the National Movement, both cooperative and non-cooperative (Sumarno et al. 2019). One of them was called Sarekat Islam (Apipudin 2019). The entry of the Sarekat Islam to the Bolaang Mongondow area was initially inseparable from religious issues, but on its way, they paid attention to various fields, especially social field.

Social inequality in the field of science was felt when the existence of the HIS Sekolah Rakjat (Hollandsch Inlandsche School) managed by the government or Nederlandsche Zendings Genootschap (NZG) only for children of officials, Christian community, and noble descent. Meanwhile, the school did not accept children who were not of those groups, including children of Muslims who were classified as well off. Seeing the condition of education in Bolaang Mongondow at that time, Sarekat Islam tried to devise a strategy to create an educational institution because many indigenous children were not educated.

Studies on the emergence of educational institutions in Bolaang Mongondow are rarely conducted comprehensively. At least two of Kosel's research articles published in 2005 and 2010 can illustrate it. In the first article, Kosel (2005) departed from missionary activities that naturally attracted more attention and tended to be better documented than those that did not. However, he focused more on Christian mission projects in the nineteenth century that had little success in transforming the native population of Bolaang Mongondow, who were predominantly Muslim.

In his second article, Kosel (2010) only mentioned briefly the emergence of educational institutions as evidence of the spread of Islam in this region. The educational institution that Kosel meant was a formal education initiated by Sarekat Islam and Christian missionaries from Minahasa. However, Kosel explored more of the Islamization process in Bolaang Mongondow, so that studies of educational institutions in this area 
were neglected. Therefore, in contrast to Kosel, this paper wants to see from another perspective that is how Islam and Christianity struggled in the establishment of formal educational institutions in Bolaang Monggondow between 1905 and 1942 .

\section{Method}

This paper uses historical research methods (Kuntowijoyo 2013, 69). In examining the topic, the writer uses historical research stages. The first is data collection (heuristics). Sources of data are taken from written ones e.g. books, journal articles, archives, newspapers, and magazines. The second is historical source criticism. The author verifies to obtain the data validation along with the heuristic stages. Afterward, the source validity test was conducted through external and internal criticism of the source. For local historical sources of the entry of Christianity and Islam in Bolaang Mongondow and historical sources written by the Dutch include in sources about the entry of Zending and Sarekat Islam to Bolaang Mongondow. Their authenticity is assessed by identifying the source of the writer, type and style of writing, material and style of language, words and sentences, as well as expressions in writing. Besides, internal criticism is carried out to see the credibility of sources by comparing one source of writing with another. It is done by sorting sources from books, journal articles, and other supporting documents by selecting and choosing relevant sources to produce facts that can be used as elements of historical composition or reconstruction.

The third is to interpret historical sources (interpretation). Stages of interpretation are intended to make the data as a fact carried out with the appropriate theories. The writer then made two kinds of interpretation, namely analysis and synthesis to describe all the data and to unify the existing data to find out the combination of the sources used which then in a structured way become a single unified word and sentence. Thefourth is to write research results (historiography). The stage of the results writing is an imaginative reconstruction of the past based on the data obtained through the process. The writing of the report is compiled based on serialization (chronological, causation and imagination). It specifically highlights historical times and events, as well as other important elements such as actors involved in history; places and causes; narrating history and the role of memory collectively and individually; objective; and looking at various types of historical writing, historiographical interpretation, and 
topography. After all the stages are carried out, then the authors write the results of the interpretation and synthesis into writing.

This study uses several research approaches. The first is the sociological approach. Historical construction by this approach can be said to be social history because it includes social groups that play a role, types of social relationships, conflicts based on interests, social strata, social roles and status, and so on. Methodologically, the aim is to understand the subjective meaning of social behavior, to search for the meaning aimed at individual actions, and to discover the motives for an event. The second is the religious approach. This approach is used to view religion from three points of view. Substantively, religion is seen from its essence which is often understood as a belief. Functionally, religion can be seen in terms of its role. Symbolically, religion is seen in symbolic reality in the form of objects, behavior, myths, legends, and so on, which are considered central in religion. The third is the political approach. This approach is used because history is synonymous with politics, such as war, diplomacy, and the actions of political figures. In particular, the author wants to look at the distribution patterns of power by studying the nature and objectives of the political system, structural relationships in the political system, individual and group behavior patterns, and legal and social policies which include: political parties, groups of interest, communication and public opinion, as well as bureaucracy and administration.

\section{Islamic and Christian struggles}

The influence of Islam and Christianity has existed in the area of the Bolaang Mongondow Kingdom since the 17th century. This is different from the Minahasa people who have known Catholic Christianity since the 16th century through several Catholic priests who were assigned to spread religion. Meanwhile, Protestant Christians in Minahasa were brought directly by Protestant pastors at the same time as the entry of Vereenigde Oostindische Compagnie (VOC) in the 17th century (Amin 2012), but it was not developed. Mass Christianization of the Minahasa people occurred during the Dutch East Indies era in the mid-19th century when Nederlandsche Zending Genootschap (NZG) sent Christian missionaries which then massive Christianization occurred as $\operatorname{Krüger}(1968,108)$ said that in 1830 the NZG sent Riedel and Schwarz to Christianize Minahasa. In the 50 years to 1880 , three-quarters of Minahasans converted to Protestant Christianity. In line with Krüger, Gunning (1924) said that at the end of 
the 19th century, the majority of the Minahasa people had embraced Christianity. Islam itself has existed since the 17 th century through certain communities. Kampung Jawa Tondano, for example, in the mid-19th century, had been formed as a Muslim community which was founded by an exiled Dutch scholar named Kyai Modjo and some of his followers (Pinontoan 2018, 108).

With the entry of Islamic influence, the Bolaang Mongondow community began to abandon animism beliefs (Kruijt 1906, 19). During the reign of King Loloda Mokoagow/Datu Binangkang (1660), Islamic preachers tried to meet and broadcast Islam to the king, so that the first to embrace Islam was the king. This is what Burhanudin $(2012,27)$ called "the king contributed to the Islamization process in the archipelago and was integrated into the local political system centered on the king from the start". That was why, Islam in Bolaang Mongondow was previously called "agama in datu" (king's religion) (Mokodenseho 2020, 59). By accepting Islam, kings did not threaten the ideological basis of the kingdom, on the contrary, the king played a role and strengthened the political ideas of those in power (Milner 1983).

Islam entered Bolaang Mongondow through two places where the former royal palace was located, namely Bolaang and Kotobangon (Research Report 1977). Regarding the route of entry to Islam, historians have different opinions. The first opinion said Islam entered through the trade of the Bugis people, while the second opinion said Islam entered through Gorontalo. However, Lopez accommodated both by referring to the travel of European missionaries N.P. Wilken and J.A. Schwarz to Bolaang Mongondow in 1866 that Islam already existed in Kotabunan through the active spread of Bugis and Gorontalo traders (Lopez 2018, 109). Lantong $(1996,63)$ and Lopez $(2018)$ then identified Gorontalo traders who brought Islam by referring to Imam Tueko.

Meanwhile, Catholicism became known to the public during the reign of King Jacobus Manoppo (1670/1689) (Mokodenseho 2020, 61). In several decades, Catholicism had only been led by teacher Jacobus Bastian. After Bastian died, no one was sent as a replacement. In the territory of the Bintauna Kingdom, religion was brought by a Paderi from Ambon, Talhatu. In his book, Doren $(1860,12)$ mentioned that the population of Bintauna consisted of Christians with a population of about 700 inhabitants. Apart from Catholicism, Protestant Christianity was allowed by the Dutch to enter Bolaang Mongondow in 1905 (Mokodenseho 2020, 61). 
Islam then developed in the royal family. According to oral history, Eugenius Manoppo (King Bolaang Mongondow in 1760) was married to Indoi and was blessed with a child named Putri Hontimimbang. At that time, King Eugenius Manoppo professed the Catholic faith and settled in the Langowan Region. Later in his old age, he returned to Kotobangon until he died in 1810. Finally, Putri Hontimimbang was taken care of and raised by the kingdom in Bolaang. Then over time, the boats of Bugis traders called Pandekawang arrived in Bolaang waters. The boat group was led by a Muslim Bugis aristocrat named Andi Latai and a follower. They and the Pandekawang's fleet were involved in a battle at sea and then landed at the bank of the Sumoit river which was the territory of the Bolaang Mongondow Kingdom.

They then asked for protection from the kingdom, the king then allowed them to rest there. In short, at the palace of the king, Andi Latai saw Hontimimbang and asked her to marry based on Islamic teachings. Andi Latai 's proposal was accepted by the king on the condition of paying a large amount of money because a daughter would convert from the Catholic to Islam. After all the requirements were met, a marriage was carried out based on Islamic teachings. Since then, Islam has entered the kingdom after several decades, which was since the reign of King Loloda Mokoagow. Andi Latai then wondered, because even though the kingdom was led by a king adhering to the Catholic faith, but he never saw a church in this area. So, he concluded that the Catholic faith only existed in the palace environment, while the people did not follow the king's religion, which was Catholicism (Mokodenseho 2020, 63). Andi Latai and his wife were blessed with six children whom all embraced Islam. The third child of them was named Andi Panungkelan, who by him was given the title Khatib Besar and in the end was appointed as a King of Bolaang Mongondow known as King Abram Sugeha (Dunnebier 1984, 65).

Islam continued to develop in the 19th century (Franklin 2020), when North Sulawesi, including the territory of the Bolaang Mongondow Kingdom, was visited by Islamic traders and preachers named Sayyid Salim bin Saleh bin Jindan who later lived and settled in the Belang area. Rusli, as quoted by Mokodenseho (2020, 63-64) said that the Belang area was still part of the Bolaang Mongondow Kingdom. On his journey, Sayyid Salim's son, Sayyid Umar, married the daughter of King Cornelis Manoppo named Putri Launa. Then Sayyid Husein bin Saleh bin Jindan, it was stated in the literature, lived in the Tondano area. If it was true that a trader and 
preacher whom the writer mentioned both lived in the Tondano area, then this strengthens the opinion of Pinontoan $(2018,108)$ that in the middle of the 19th-century, Muslim communities had been formed in Tondano. Meanwhile, Sayyid Husein himself married a woman named Syarifah Alawiyah. It was stated in the literature that the grandmother of Syarifah Alawiyah was the son of the former head of the Belang Region named Mayor Koagow (Mokodenseho 2020, 64). The author concludes that the good relationship between the rulers of the Bolaang Mongondow Kingdom and the Hadramaut people had facilitated the propagation of Islam in this area.

When Jacobus Manuel Manoppo ruled the Bolaang Mongondow Kingdom (1833-1858), he also embraced Islam through his marriage to Hakim Bagus' daughter from Gorontalo named Kiling/Kilingo. Since then, Islam began to enter Bolaang Mongondow and became the official religion of the kingdom. According to M.A. Sugeha (Abo 'Andung Sugeha), as quoted by Ginupit, he said that Islam entered Bolaang Mongondow by a teacher from Gorontalo named Imam Tuweko/Temij Raupu, precisely during the time of King Jacobus Manuel Manoppo. Imam Tuweko had a daughter named Kilingo. While another source states that the religion of Islam at the time of King Jacobus Manuel Manoppo was brought by Hakim Bagus who also had a daughter named Kilingo (Ginupit 2003). Thus, the authors conclude that it was a Quran teacher named Tuweko who later earned the nickname Hakim Bagus. The author's analysis is based on the names of the two children whose both have the name Kilingo.

The development of Islam made Islamic culture influence the lives of the local community, so that in Bolaang Mongondow it was known as "adat bersendikan syara' and syara' bersendikan Kitabullah" ("tradition based on sharia and sharia based on the holy book of God") (Manorek 1998, 25). Another source said that more than $50 \%$ population of Bolaang Mongondow in 1866 had embraced Islam, and the rest was animists (GMIMB 1967, 1). This information was corroborated by Kosel (2010), Jansen (1857, 20), Riedel (1864), Ulfers (1868), and Clercq (1883) that in the late 1850s and 1860s, the Muslim population in Bolaang Mongondow reached 50 percent. However, the understanding of Islam was not so "good" because religious rationalization did not begin with the establishment of formal institutions and the professionalization of religious leaders, but was limited to changes in world views. The essential readiness to convert was displayed by the 
ruling elite in the early 19th century, and it might be hoped that the small population contributed to the relatively rapid acceptance of Islam.

The increasing number of Muslims, according to the author, had something to do with the presence of a scholar from Mecca. In the 1860s, Bolaang Mongondow was visited by a scholar named Syekh Abdul Latief Rezik Makki with the Syafii sect. It can be said that the arrival of the Ulama (Islamic teacher) at Bolaang Mongondow was a marker, as well as a sign of starting point for the pattern of spreading Islam through the share of Islam (education), as well as the needs of the authorities and the local community regarding a figure who understood Islam. Syekh Abdul Latief Rezik Makki was a scholar promised by the Resident of Manado based on the request of King Jacobus Manuel Manoppo who was named the Sultan after his marriage to a Muslim woman named Kiling or Kilingo. During the reign of King Adrianus Cornelis Manoppo (Dunnebier 1984, 65), this scholar married to Boki Besar Bua Bulawan Manoppo but they did not have children. Then he again married to Bai Edong Mokoagow from Moyag Village and was blessed with four children named Hania, Mahadi Rezik Makki, Madani Rezik Makki, and Mohammad Rezik Makki (Brouwer 1930, 27). Since that time, the influence of Islam had become stronger in the Bolaang Mongondow community.

The existence of the figure of a scholar who spread Islam in Bolaang Mongondow after the marriage of King Jacobus Manuel Manoppo created differences among historians. Ginupit (2003) said that when the Resident of Manado heard that King Jacobus Manuel Manoppo had embraced Islam, the Dutch government brought in a Quran teacher (Donggala Arab descent) named Syarif Abdul Latief Al-Gaus to spread Islam in Bolaang Mongondow. The Quran teacher married a widowed woman named Bai 'Boit Makalalag. His descendants later continued the family name with the Makalalag clan in this region. However, the same source also said that after King Jacobus Manuel Manoppo was named sultan, he asked Sultan Kutai to send a Quran teacher to Bolaang Mongondow, and this was granted by Sultan Kutai by sending an Arabic Quran teacher named Mohammad Rezik Makki. The Quran teacher was placed by the king in Moyag Village, so that Islam quickly spread to nearby villages, such as Bongkudai, Modayag, and Motongkad. In revealing who exactly Sheikh Abdul Latief Rezik Makki and Syarif Abdul Latief al-Gaus, it was difficult to reveal because of the lack of sources to explain. However, the authors believe, the two people were the same person. 
In addition to the fact that many had embraced Islam, the Dutch government did not allow evangelicals to spread their religion in Bolaang Mongondow. The reason was that a Dutch official had not yet been assigned there. It was not until the deployment of A.C. Veenhuyzen Controller in 1901 (Hekker 1991), then around 1904-1905, Christian missionaries spread their mission in Bolaang Mongondow (Suwondo 1978, 102). Brouwer $(1930,54)$ said that in 1904, the number of Christians in Bolaang Mongondow reached 1,500 and increased to 6,800 in 25 years (1904-1929).

\section{Dynamics of Education in Bolaang Mongondow}

Initially, the conditions of education in Bolaang Mongondow were underdeveloped compared to other areas in North Sulawesi. The Minahasa, for example, before the Dutch applied ethical politics, educational institutions existed in the region. In 1934, Minahasa had 170 schools, some even mentioned 184 schools in 1918 which were specifically managed by the NZG (Krüger 1959, 102). Meanwhile, in the context of Bolaang Mongondow until the end of the 19th century, the government did not pay any attention to creating educational institutions, except during the time of King Ismael Cornelis Manoppo (1829), until he was replaced by King Jacobus Manuel Manoppo (1830-1858). It had been recorded that the capital of the Bolaang Mongondow (Bolaang) Kingdom already had a school. However, in 1831 the school was closed by the Dutch because the only teacher named Jacobus Bastian had died and a replacement teacher was not immediately sent (Ridder, 1867, 7). In 1848, King Jacobus Manuel Manoppo went to the Resident of Manado and asked for the opening of the Gubernemen School in Bolaang, but was refused. It was later discovered that the closure of the school was due to a lack of attention and interest from the Mongondow people. In fact, Jacobus Bastian was honorably discharged by the Dutch through a Decree (Besluit) of the Resident of Manado D.F.W. Pietermaat, March 17, 1831 (Ginupit 2003). Thus, each parent played an important role in the education of Bolaang Mongondow's children.

The attention to the education of Bolaang Mongondow's children was seen again during the time of King Riedel Manuel Manoppo. The king sent his two children, Johanis Manuel Manoppo and Jacobus Manuel Manoppo to receive formal education at Hoofdenschool Tondano (Minahasa) around 1897-1902. Although the King was known to be anti-Dutch, he realized that 
education was important for the people and the advancement of the kingdom. However, the school could only accept children and the royal family, as well as the children of government officials (aristocrats) such as the District Head. Hence, the school was commonly called the King's School such as Kweekschool in Bukittinggi, West Sumatra which was founded by the Dutch in the 1859 (Abdullah 1970). In 1897-1902, there were only four Bolaang Mongondow children who successfully graduated from this school, who were King Riedel Manoppo's brother/nephew named Herman Manoppo and the son of Raja Ram Suit Ponto (Raja Bolaang Itang) named Fillip Ponto (Parengkuan 1978, 10-11).

In the early 20th century, education began to develop in Bolaang Mongondow which was marked by the establishment of schools. In 1906, with the permission of the Netherlands, Nederlandsche Zending Genootschap (NZG) opened 14 Sekolah Rakjat (SR) in the Bolaang Kingdom of Mongondow (Manggo 2003, 4; GMIMB 1967, 3). These schools were alternately managed by two pastors, Dunnebier and Langeveld, and assisted by several Christian teachers from Minahasa (Mokodenseho 2020, 197). Then in 1911, a Dutch school was opened for indigenous children known by the name of Hollandsche Isnlandsche School (HIS) (Chudy et al. 2016). In 1926, Sarekat Islam through the Islamic Education and Teaching Center (BPPI) established an Islamic school, and the teachers were from Java, Gorontalo, Manado, Sangir Talaud, and Tondano, as well as teachers from Bolaang Mongondow itself (Suwondo 1978, 148). With the development of BPPI education, in 1931 Sarekat Islam opened another HIS school in Dutch as the language of instruction in Molinow Village. To prepare prospective teachers at BPPI, in 1937 the Sarekat Islam opened Kweekschool (School of Teacher) in Molinow Village (YPC 2009).

During its development, the private sector was trying to open Dutchlanguage schools such as Particuliere School which was opened by AC Manoppo, and Netrale Particuliere School by AE Lewu. The same school was also founded in 1925 by Sumual but discontinued. In 1937, Vervolg School was founded (grade 4 and 5 connection schools) which was located near the HIS school, and the principal was N. Ares. However, these schools were closed when Japan occupied Bolaang Mongondow in 1942. The name of the school was changed to the Japanese Folk School for five years (Futsu Joukyu Ko-Gakko). In 1943, Japan opened Kyooin Kosyukai (Short Course for Teacher) to educate alumni of the Sekolah Rakjat for 3 years to become 
teachers. The teacher's school was headed by H. Senduk with 3 months of education. After graduating from the school, they were employed as teachers in schools scattered in Bolaang Mongondow (Ginupit 2003, 26).

After Japan surrendered in 1945, HIS was reopened under the name Class 5 Public Elementary School (Algemene Lagere School) with E.P. Suling as the principal. Then, during the time of the State of East Indonesia (NIT) precisely in 1946, Normaal School was opened in Kotamobagu as an advanced Public School which specifically educated prospective teachers with 4-year study period. This school was a little different from before. Students who were prospective teachers were hired with the hope that they would become proficient, disciplined, and had good personalities. In 1952, Normaal School was changed to be School of Teacher B, headed by A.F. Lumowa. However, because the NIT had joined the Unitary State of the Republic of Indonesia (NKRI), then, Algemene Lagere School transformed into a 6-year Elementary School, and at the same time served as a place to practice teacher candidates from SGBN Kotamobagu.

In 1954, the 2-year Technical School was founded under the leadership of Manossoh. In 1960, SGBN was abolished and at the same time the Bolaang Mongondow government, in this case, Daan Olii as the Regent, also opened three schools, namely the State Senior High School, the State Senior High School for Economics, and SGAN under the coordination of Johan F.L. BA. The three schools mentioned were opened at once and were located in the former SDN 3 (Elementary School) Biga. In 1962, SGAN was transferred to the former seat of SGBN, while SMEA Negeri (Public Senior High School) was located next to SMP Negeri 1 (Public Junior High School) Kotamobagu. Since that time, all Sekolah Rakjat in rural areas have been converted into 6 Grade Public Elementary Schools. In its development, besides the opening of State Elementary Schools (SDN), State Junior High Schools (SMP), and Public Senior High Schools (SMA), the private sector both Islamic, Catholic, and Protestant Christian Education Foundations, also opened Private schools for SD, SMP and SMA level (Ginupit 2003, 27). Thus, because in Bolaang Mongondow schools had been built ranging from kindergarten, elementary, junior high, and high school levels, to tertiary institutions, education in this area had progressed like in many areas in North Sulawesi, and Indonesia in general. 


\section{Missions Education Institute (Christian)}

Referring to the previous discussion, education in Bolaang Mongondow only began to develop in the early 20th century. The only schools that existed were schools managed by Nederlandsche Zending Genootschap (NZG). Since 1906, the NZG opened the Sekolah Rakjat (4-year study period) (Manggo 2003: 4; GMIMB 1967: 3). From the beginning of its establishment, it was noted that dozens of school buildings were successfully built (Iman 1984: 6). The Sekolah Rakjat were founded by missionaries Dunnebier (1907) when he arrived di Bolaang Mongondow (1905). He opened fourteen Sekolah Rakjat during 1906. Interestingly, although female students were allowed to enter the Sekolah Rakjat, it appeared that there was difference in number; 1,349 male students and 556 female students.

To help the process of educating the Sekolah Rakjat, the Netherlands brought in 30 Christian's teachers from Minahasa. They were also supposed to be leaders of the local Christian congregations under Dunnebier's supervision (De Sumatra Post 1937). After approximately 30 years Dunnebier broadcasted Christian missions in Bolaang Mongondow, he was replaced by Langeveld. The mission aspect of the school was most successful in villages with Minahasa ethnic populations, such as Poopo, Mariri, and Dumoga, where Islam did not yet have strong roots. After decades of mistreatment by local rulers, the Minahasa settlers in Bolaang Mongondow found that Christianity provided an opportunity to assert their distinctiveness in positive ways. Through repentance, they were able to forge new bonds with their homeland, claim equality, have high status in the colonial hierarchy to his peers in Minahasa and probably hope to be favored by the Dutch rulers who had just arrived in Bolaang Mongondow (Kosel 2005).

The establishment of Sekolah Rakjat (SR) and teaching staff houses, apart from being assisted by the Dutch, was also borne by the financial characteristics of the Bolaang Mongondow Kingdom, and money (school fonds) originating from the tax bearer community (Mokodenseho 2020, 72 73). With great assistance, all the Sekolah Rakjat managed by the NZG were successful to register 1905 students. The number of Sekolah Rakjat in 1911 became 16 with 1394 students and continued to increase in 1934 by the number of 30 . The schools under the NZG continued to survive until the Japanese colonized Bolaang Mongondow in 1942 (GMIMB 1967, 3). 
In 1911, there was a desire to accommodate the aspirations of the noble children of the Bolaang Mongondow who wanted to enter a better school than the Sekolah Rakjat, such as Europeesche Lagere School (low school for Westerners) in Manado. However, because they could not afford it, a Dutch school was established for indigenous children known as Hollandsche Inlandsche School (HIS). The school building was in the form of a long shop owned by King Datu Cornelis Manoppo facing the guest house of the controller who was also a Dutch teacher named A. Van der Endt (Algemeen Handelsblad 1930). For the children of indigenous aristocrats, HIS was the best school to get an education and at the same time increased social status, because the school was originally only reserved for the elite. After the implementation of ethical politics, this school could then be entered by children from the lower classes. In Bolaang Mongondow, NZG founded HIS Kotamobagu, and it was not until 1919 that they started accepting students from the "simpal" (next door) group whose parents had the position of Village Heads.

There were four assessment criteria for admission to HIS schools, including; aristocratic or the descent of rich people; parents of students who had positions or government employees; wealthy parents; and parents who had attended a Dutch school. In addition, the Netherlands also relied on the annual income of parents. Of the four criteria mentioned, it was then divided into three categories. Category A included aristocrats, government officials, and private workers who earned more than 75 guilders per month. Category B were parents graduating from Kweekschool and Meer Uitgebreid Lager Onderwijs (MULO) School. Category C were small entrepreneurs, ordinary employees, HIS graduates, farmers, and fishermen. Those in category $\mathrm{C}$ were considered as middle to lower-class families, while category A and B were prioritized to attend HIS schools (Prayudi and Salindri 2015). In Bolaang Mongondow, teachers, MULO, and schools under the government and private sector were only known at the beginning of the 20th century (Mokodenseho 2020, 74-75). The Dutch were very selective towards HIS Kotamobagu where the registrants were limited to only about 24 people in the first year (GMIMB 1967, 3). The students of HIS school who were Muslim were immediately sent by their parents to Gorontalo to study Islam, such as the Quran and the basics of other Islamic religions. Afterward, they returned to Bolaang Mongondow and joined the Sarekat Islam. 


\section{The emergence of Islamic Education Institutions}

The entry of Sarekat Islam in Bolaang Mongondow (1920) was the beginning of the establishment of Islamic schools. In 1923, Sarekat Islam Center held a congress in Manado which was named "Nationale Propinciale Celebes Congres". The congress was chaired by HOS. Cokroaminoto, A. M Sangaji and Arudji Kartawinata, and attended by Hajjah Oemar Said Cokroaminoto (Chair of the Central PSII Woman). The congress participants consisted of all groups and strata of society who came from the Minahasa area and its surroundings. While representatives from Sarekat Islam of Bolaang Mongondow was attended by 5 delegates from the congress, namely Pudul Imban, Mustafa Mokobombang, T. Dilapanga, Unta Mokodongan and Dapo Londa as assistants. The congress resulted in two decisions, one of which was advancing onderwijs (education) in Bolaang Mongondow (Manggo 2003, 6).

Following up the results of the congress, around 1925, the board of Sarekat Islam held a general meeting in Molinow Village to discuss the establishment of the school. One of the results was to give a mandate to Adampe Dolot to take care of the license for the school establishment. After Adampe Dolot accepted the mandate, he then went to the king and controller in Bolaang Mongondow, as well as the Resident in Manado, but on his way, the effort failed. The Resident of Manado refused because the authority and permission to establish a school had been granted to NZG. Hearing this statement, with the support of Sarekat Islam of Bolaang Mongondow, Adampe Dolot immediately went to Yogyakarta to meet Cokroaminoto and Suryopranoto. The two Sarekat Islam figures suggested that Dolot should face the General Governor (GG; Gouverneur Generaal) in Batavia. With this suggestion, Dolot returned to Batavia and went to the General Governor, and received an explanation that there was no need to establish a government school (gouvernement scholen) as the NZG founded. He was directed to open Particuliere School (Private School) such as the Taman Siswa School or Yogyakarta Adhi Dharma College which was fostered by Suryopranoto (YPC 2009).

After the permit to open the school was approved by the General Governor in Batavia, Adampe Dolot, assisted by AP Mokoginta, came to Departmen Van Onderwijs En Eredenst (the Ministry of Education and Culture) to take care of the requirements regarding the establishment of 
schools. Upon his return from Batavia, he then went to the Resident in Manado and Raja Bolaang Mongondow to deliver the news. Hearing Adampe Dolot's report, the king had no objections. In 1926, the Islamic School in Molinow Village was opened with the name of the Islamic Education and Teaching Institute (BPPI HIS 5 Years). The teachers who were assigned to teach in that school were Lasaru Detu, B. Imban, L. Imam and B. Hayat (Manggo 2003, 6-7). With the opening of the BPPI School, there were two religious organizations that managed education in Bolaang Mongondow, namely NZG and Sarekat Islam.

The Islamic School began operating on July 1, 1926, with an approximately 500 students. The building used to support the learning process was the BPPI Molinow building (Cokroaminoto Elementary School now). At that time, the BPPI building was still an emergency with a size of $45 \times 16$ meters, and the school ended in 1930. During the 5-year HIS period, to meet teachers at BPPI Molinow and Tutuyan, a 6-month teacher training was held which was taken from graduates of NZG Kotamobagu and its surroundings, as well as graduates with names Curcus voor Volks Onderwijzer $(\mathrm{CVO})$ and Kweekeling. Apart from that, prospective BPPI teachers were sent to the college of Kweekschool Adhi Dharma Yogyakarta gardually financed by the Sarekat Islam. They were Haruna Pundong, Zakaria Imban and Yahya Mokobombang (YPC 2009).

In 1931, Holland Inlandsch School (HIS) BPPI was founded for 7-year study period as a continuation of the 2-year Sekolah Rakjat. To meet the teaching staff, besides local teachers, teachers from Java were also brought in, including alumni from the Adhi Dharma college in Yogyakarta (Suwondo 1978, 148; Ginupit 2003, 25). Thus, the school that was opened by Sarekat Islam was also supported by teachers that almost all of them were Javanese intellectuals. Of the teachers imported from Java, only Raden A. Harjodiwirjo lived in Bolaang Mongondow until he died in Molinow on December 12, 1994. Meanwhile, students who were studying at HIS BPPI for 7 years were not only from Molinow, but also from Bolaang Mongondow, Kotamobagu, Bolaang Mongondow Timur, Bolaang Mongondow Selatan, Bolaang Mongondow Utara and Ratatotok (Southeast Minahasa). The curriculum used by the school was balanced between Islamic Religious Education and general knowledge with the cooperation of 45\%: 55\%, as well as used Indonesian, Arabic and Dutch as the language of Instruction (YPC 2009). 
In 1939, the results of the teacher nursery education were sent throughout the Bolaang Mongondow area. With the full support of administrators and members of the Sarekat Islam, schools had also been established in the villages under the auspices of the Islamic Education and Teaching Center (Iman 1984, 19-20; YPC 2009; Imban 1970, 10). Since the BPPI school was founded by Sarekat Islam, this organization had completed about $80 \%$ of the total school-age children in Bolaang Mongondow (Iman 1984, 10). All Sarekat Islam schools were funded by community organizations, members of Sarekat Islam, and endowments of Sarekat Islam. The teachers were taken from alumni of Kweekschool, CVO, and Kweekeling.

HIS BPPI lasted until 1946. It was then adjusted to the name of the BPPI Cokroaminoto Sekolah Rakjat. With the existence of the Minister of Education Regulation, the school was transformed into the BPPI Cokroaminoto Elementary School as well as adjustments in school management, that required to have a legal entity. Thus, the Regional Leadership Council of the Sarekat Islam in North Sulawesi Province established a legal entity called the Cokroaminoto Islamic Education Foundation, which was domiciled in Manado. However, along with the development of regional autonomy to accelerate services to elementary schools, the Cokroaminoto Education Foundation for Bolaang Mongondow Regency was established with notarial deed number 28 dated May 18, 1989, from Notary Urip Manoppo, SH. Entering the New Order, many Cokroaminoto Elementary Schools were abandoned because the Cokroaminoto Education Foundation was considered to be affiliated with the Indonesian Sarekat Islam Party (PSII). After the Party Fusion, PSII joined the United Development Party (PPP). So since then, there were many Elementary schools in Bolaang Mongondow.

The Cokroaminoto Bolaang Mongondow Education Foundation already existed and was formed on July 1, 1926, under the name Islamic Education and Teaching Foundation (BPPI). In the further development of the foundation, in 1984 the name of BPPI was changed to the Cokroaminoto Islamic Education Foundation (YPIC) North Sulawesi with notary deed No. 43. In 1989, YPI Cokroaminoto separated from North Sulawesi Province and was established autonomously by the name of the Cokroaminoto Bolaang Mongondow Educational Foundation (Deed of Notary Number 28 of 1989). Then with the issuance of the Law of the 
Republic of Indonesia No.16 of 2001 and No. 28 of 2004 which regulated the foundation, the name of the foundation was adjusted and changed to the Cokroaminoto Bolaang Mongondow Raya Educational Foundation based on the Notary Deed Number 42 of 2013 (Mokodenseho 2020, 159$60)$.

Apart from the establishment of HIS BPPI, Kweekschool (4 years of teachers' meeting) was also founded in 1939 as a continuation of the HIS BPPI school. All the needs and interests of teachers within the Bolaang Mongondow Sarekat Islam Party (PSI) were taken from the Sarekat Islam plantation business and the self-help of its members (Imban 1970, 8-9), but Kweekschool on its development has changed. In 1950-1952, Kweekschool changed to the Public Education Center (BPU) at the junior secondary level. Then in 1953-1955, it was changed to Islamic Secondary School (SMI) at the SLTP level. In 1956, it was changed back to the Cokroaminoto Junior High School (SMP). While the building used was the current Cokroaminoto Junior High School building which is on Jalan Adampe Dolot. In addition to the school which is located on Jalan Adampe Dolot, at the request of the Bongkudai Village community, SMP Cokroaminoto Bongkudai was also opened in 1960. After the issuance of the Decree of the Minister of Basic Education and Culture of the Republic of Indonesia No. 45/S/Um Manado, February 19, 1965, signed by R.E. Kalempou (Head of Regional Representative Office for PD and K Regional North Sulawesi), SMP Cokroaminoto Molinow was recognized with subsidized status (Mokodenseho 2020, 163-64). The first batch of this school accepted as many as 25 students by involving teachers from HIS BPPI and graduates of Adhi Dharma Yogyakarta. The goal was that all villages in Bolaang Mongondow could be established by HIS. The school building was located on Jl. Veteran No. 1, West Kotamobagu, which is currently serving as the Kotamobagu City Islamic Council Office, and the Cokroaminoto Bolaang Mongondow Raya Education Foundation Office.

Sarekat Islam, to advance the education of Bolaang Mongondow Muslim children, did not only stop at how to develop Islamic and general knowledge, but also strived for Bolaang Mongondow children to become skilled at a young age. The reason is that the next generation of the nation requires the inculcation of the values of independence and democracy so that later they do not easily enter into a social problem over differences. To instill a spirit of patriotism and nationalism in the nation's generations, Sarekat Islam organized scouting education based on Islam which was started 
from the opening of HIS BPPI in 1931 as explained earlier. Thus, one of the Sarekat Islam figures who was also a BPPI HIS teacher that was sent from Java named Ramelan D. established a scouting branch of the Sarekat Islam Angkatan Pandu (SIAP). SIAP members consisted of Islamic School students and HIS BPPI throughout the Bolaang Mongondow area and consisted of two parts. In scouting activities, besides the Scouting Principle, students also learned various kinds of skills, including; skills of vlag seinen or semaphore, morse code, searching traces, Eerste Hulp Bij Ongelukken (EHBO), arts and sports, and first aid. However, the most important thing was to instill the spirit of patriotism, love of religion, nation, and homeland. Scouting activities were designed to increase nationalism and love of religion such as a campfire, a comedy that evokes the spirit of patriotism and shows with Islamic nuances. In addition to being an internal regeneration education for Sarekat Islam, scouting education was also a nonformal education aimed at arousing the spirit of nationalism.

The Islamic education in Bolaang Mongondow, which was initiated by Sarekat Islam, can be said to be quite successful. The increase in the social status of the community through education can be felt when independent Islamic education institutions were established for the continuation of the education of Bolaang Mongondow Muslim children. With this education, besides general knowledge regarding nationalism, an understanding of Islam also developed well in this area. Furthermore, these educational institutions contributed to the creation of educated cadres and those of the national movement. Almost all independence fighters who were Muslim in Bolaang Mongondow were members of the Sarekat Islam and alumni of its schools under the auspices of the BPPI Foundation.

\section{Conclusion}

The entry of Islam and Christianity contributed to the creation of educational institutions in Bolaang Mongondow. Islamic education institutions were only initiated after the arrival of Sarekat Islam. Through the Islamic Education and Teaching Center (BPPI), Sarekat Islam on 1 July 1926 established the Molinow Islamic School. The school ended in 1930 with a graduate student population of 500. In 1931, the Sarekat Islam opened Holland Inlandsch School (HIS) BPPI for 7 years program. The Sarekat Islam then opened Kweekschool (School of Teachers) in 1937 with a study period of 4 years. Apart from formal private schools, Sarekat Islam 
established a scouting school, Sarekat Islam Angkatan Pandu (SIAP), to train the skills of students who graduated from Islamic Schools and BPPI Schools. In a short time, Sarekat Islam succeeded in opening 34 schools scattered throughout the Bolaang Mongondow Kingdom. Schools run by Catholic Christian missionaries existed during the reign of King Ismael Cornelis Manoppo (1829) but were officially closed by the Dutch in 1831. Missionary schools administered by Nederlandsche Zendings Genootschap (NZG) appeared again in the early 20th century along with the entry of Protestant Christian missionaries in Bolaang Mongondow in 1905. A Protestant Christian missionary named Pastor Dunnebier with the permission of the Dutch opened 14 Sekolah Rakjat in 1906 and managed to register 1,905 students. The number of Sekolah Rakjat in 1911 became 16 with 1394 students and continued to increase in 1934 by the number of 30 . The schools under the NZG continued to survive until Japan colonized (1942-1945). Thus, between 1905 and 1942, Bolaang Mongondow had two educational institutions, namely an educational institution initiated by Christian missionaries with the permission of the NZG and Islamic education initiated by Sarekat Islam.

\section{References}

Abdullah, Taufik. 1970. "Some Notes on the Kaba Tjindua Mato: An Example of Minangkabau Traditional Literature.” Indonesia (9): 1-22.

Algemeen Handelsblad. 1930. "Ned. Zendings-School." Algemeen Handelsblad:

https://resolver.kb.nl/resolve?urn=ddd:010661519:mpeg21:a0257.

Algemeen Verslag. 1941. Algemeen Verslag van Het Onderwijs in Nederlandsch Indie over Het Schooljaar 1938-1939. Batavia: Batavia-Centrum.

Amin, Basri. 2012. "Ethnic Identity in Colonial and Postcolonial Politics: The Case of Minahasa, Eastern Indonesia." Journal of Asia Pacific Studies 2(3): 322-46.

Apipudin, Apipudin. 2019. "The Role of Sarekat Islam in Promoting the Idea of Muslim World in Indonesia (1912-1925).” MEIS: Middle East and Islamic Studies 6(2): 135-56.

DOI: https://doi.org/10.7454/meis.v6i2.100.

Arifianto, Alexander R. 2009. "Explaining the Cause of Muslim-Christian 
Conflicts in Indonesia: Tracing the Origins of Kristenisasi and Islamisasi." Islam and Christian-Muslim Relations 20(1): 73-89.

DOI: https://doi.org/10.1080/09596410802542144.

Ter Avest, K. H. (Ina), and M. (Marjoke) Rietveld-van Wingerden. 2017. "Half a Century of Islamic Education in Dutch Schools." British Journal of Religious Education 39(3): 293-302.

DOI: https://doi.org/10.1080/01416200.2015.1128391.

Brouwer, A. M. 1930. De Zending in Nederlandsch Oost-En West-Indië: Toelichting Op de Zendingskaart Door AM Brouwer: Met 26 Afbeeldingen in Den Tekst. Groningen: P. Noordhoff N.v.

Burhanudin, Jajat. 2012. Ulama Dan Kekuasaan: Pergumulan Elite Muslim Dalam Sejarah Indonesia. Jakarta: Kencana.

Burhanudin, Jajat. 2017. Islam Dalam Arus Sejarah Indonesia. Jakarta: Kencana.

Chudy, Stefan, Alena Juvova, Imron Wakhid Harits, and Pavla Andrysova. 2016. "Indonesia Education Today: Dating Back Its History of Islam and Imparting European Education System." Asian Social Science 12(5): $179-84$.

Clercq, F. S. A. de. 1883. "Schets van Het Landschap BolaängMongondow." Tijdschrift van het Koninklijk Nederlandsch Aardrijkskundig Genootschap (7): 116-25.

Damopolii, A. P. 1984. Sejarah Bolaang Mongondow. Kotamobagu.

Doren, J. B. J. van. 1860. Bijdragen Tot de Kennis van Verschillende Overzeesche Landen, Volken, Enz. Amsterdam: J.D. Sybrandi.

Dunnebier, W. 1907. "De Zending in Bolaang-Mongondow.” Mededeelingen vanwege het Nederlandsche Zendelinggenootschap (5): 1-21.

Dunnebier, W. 1984. Over de Vorsten van Bolaang Mongondow. Surabaya: Intan Print.

Franklin, Nathan John. 2020. "Islam and the Dutch in the East Indies: Oppression or Opportunity?" European Legacy 25(5): 572-87. https://www.tandfonline.com/doi/abs/10.1080/10848770.2020.176 0467 (April 25, 2021). 
Ginupit, B. 2003. Sejarah Bolaang Mongondow. Kotamobagu.

GMIMB. 1967. Pandangan Beberapa Waktu Secara Kronologis Dari Sejarah Gereja Di Bolaang Mongondow. Kotamobagu: Kantor Gereja Masehi Injili Bolaang Mongondow.

Gunning, J. W. 1924. "Uit En over de Minahasa II. De Protestantsche Zending in de Minahasa." Bijdragen tot de Taal-Land-en Volkenkunde: 451-520.

Hekker, M. W. M. 1991. "Vooroudercultus En Sjamanisme in Bolaang Mongondow." Bijdragen tot del Taal, Land- en Volkenkunde 147(4): 445-53.

Howard, Damian. 2016. "Christians and Muslims in Tomorrow's Europe." Studies: An Irish Quarterly Review, Irish Province of the Society of Jesus 105(419): 294-308. https://www.jstor.org/stable/24871400 (April 25, 2021).

Van Huis, Stijn Cornelis. 2019. "Khul' over the Longue Durée: The Decline of Traditional Fiqh -Based Divorce Mechanisms in Indonesian Legal Practice." Islamic Law and Society 26(1-2): 58-82. https://brill.com/view/journals/ils/26/1-2/article-p58_1.xml (April $25,2021)$.

Iman, R. 1984. Peranan Sarekat Islam Dalam Pembangunan Pendidikan Di Desa Molinow 1920-1950. Manado.

Imban, Z. et al. 1970. Perjuangan Kemerdekaan Dan Pembentukan Kabupaten Daerah Tingkat II Bolaang Mongondow. Kotamobagu.

Jansen, A. J. F. 1857. "Reis Naar N. En W. Kust van Celebes." In ANRI Manado, Jakarta: National Archives of Indonesia.

Koenig, Moritz. 2020. "Colonial Legality in Sumatra: Assemblages, Absences, and a Turn to Ontology." Indonesia and the Malay World 48(142): 359-78. https://www.tandfonline.com/doi/abs/10.1080/13639811.2020.179 6291 (April 25, 2021).

Kosel, S. 2005. "Christian Mission in An Islamic Environment: Religious Conversion in North Sulawesi in the Light of a Case-Study from Bolaang Mongondow." Paideuma 51: 41-65. 
http://www.jstor.org/stable/403418866.

Kosel, S. 2010. "The History of Islam in Bolaang Mongondow, North Sulawesi." Indonesia and the Malay World 38(110): 43-64.

Krüger, T. M. 1959. Sejarah Gereja Di Indonesia. Jakarta: Badan Penerbit Kristen.

Krüger, T. M. 1968. Der Protestantismus in Indonesien: Geschichte Und Gestalt. Stuttgart: Evangelisches Verlagswerk.

Kruijt, ALB. C. 1906. Het Animisme Der Indonesiers. Rotterdam: Electrische Drukkerij, D. van Sijn \& Zoon.

Kuntowijoyo. 2013. Pengantar Ilmu Sejarah. Yogyakarta: Tiara Wacana.

Lantong, Z. A. 1996. Mengenal Bolaang Mongondow. Kotamobagu: U.D. Asli Totabuan.

Lopez, A. C. 2018. "Conversion and Colonialism: Islam and Christianity in North Sulawesi, c. 1700-1990.” Leiden University.

Manggo, N. G. 2003. Sejarah Perjuangan Kelaskaran Banteng Republik Indonesia, Bolaang Mongondow. Jakarta: CV. Cakra Media.

Manorek, R. 1998. Perubahan Nilai Upacara Tradisional Pada Masyarakat Pendukungnya Daerah Sulawesi Utara. Manado: CV. Teratai Emas.

Milner, A. C. 1983. "Islam and the Muslim Stateo Title." In Islam in SouthEast Asia, ed. M. B. Hooker. Leiden: E.J. Brill, 23-49.

Mokodenseho, Sabil. 2020. Sisi Lain Gerakan Sarekat Islam Di Sulawesi Utara Periode 1920-1950. 1st ed. Surabaya: Jakad Media Publishing.

Mroz, Kathleen. 2019. "Mary the Bridge Builder: Rethinking Patriarchal Portrayals of Mary in Islam and Christianity." Journal of South Asian and Middle Eastern Studies 42(3): 1-19. https://www.jstor.org/stable/10.33428/jsoutasiamiddeas.42.3.0001 (April 25, 2021).

Parengkuan, F. E. W. 1978. Sejarah Daerah Bolaang Mongondow. Manado. Fakultas Sastra UNSRAT.

Pinontoan, Denni H. R. 2018. "Politik Identitas Dalam Masyarakat Multikultural Minahasa." In Praktik Pengelolaan Keragaman Di 
Indonesia: Konstruksi Identitas Dan Eksklusi Sosial, Yogyakarta: Center of Religious and Cross-cultural Studies-CRCS.

Prayudi, Gusti Muhammad, and Dewi Salindri. 2015. "Education on Dutch Government in Surabaya at 1901-1942." Publika Budaya 3(1): 20-34. http://jurnal.unej.ac.id/index.php/PB/article/view/1534 (April 26, 2021).

Research Report. 1977. Sejarah Daerah Sulawesi Utara. Manado: Proyek Penelitian dan Pencatatan Kebudayaan Daerah Sulawesi Utara.

Rhijn, M. van. 1941. Memorie van Overgave van Het Bestuur van Den Aftredenden Resident van Manado. Manado.

Ridder, J. H. de. 1867. Veertigduizend Zielen, Een Smeekstem, Aan Neerland's Zonen En Dochtere. Belanda: Belanda: Leiden University Libraries.

Riedel, J. G. F. 1864. "Het Landschap Bolaang-Mongondow." Tijdschrift voor Indische Taal, Landen Volkenkunde (13): 277.

Roff, William R. 2010. "Customary Law, Islamic Law, and Colonial Authority: Three Contrasting Case Studies and Their Aftermath." Islamic Studies 49(4): 455-62. http://www.jstor.org/stable/41581119 (April 25, 2021).

Scherer, Savitri P. 1985. Keselarasan Dan Kesenjangan: Pemikiran Pemikiran Priayi Nasionalis Jawa Awal Abad XX. Jakarta: PT. Sinar Agape Press.

Shihab, Alwi. 1998. Membendung Arus Respons Gerakan Muhammadiyah Terhadap Penetrasi Misi Kristen Di Indonesia. Bandung: Mizan.

Sumarno, Sumarno, R Aji, and Eko Hermawan. 2019. "Ethical Politics and Educated Elites In Indonesian National Movement." In Proceedings of the International Conference on Social Science 2019 (ICSS 2019), eds. Sunarto, Amni Zarkasyi Rahman, and Widiartanto. Paris, France: Atlantis Press, 368-72. https://www.atlantispress.com/proceedings/icss-19/125927086 (April 26, 2021).

De Sumatra Post. 1937. "Nood Der Zending: Heengaan Der Ouden." De Sumatra Post. https://resolver.kb.nl/resolve?urn=ddd:010383699:mpeg21:a0124.

Suwignyo, Agus. 2013. "The Great Depression and the Changing Trajectory 
of Public Education Policy in Indonesia, 1930-42." Journal of Southeast Asian Studies 44(3): 465-89. http://www.jstor.org/stable/43863216 (April 25, 2021).

Suwondo, Bambang. 1978. Sejarah Kebangkitan Nasional Daerah Sulawesi Utara. Jakarta: Direktorat Jenderal Kebudayaan.

Ulfers, S. 1868. "Het Rano-i-Apo-Gebied En de Bevolking van Bolaang Mongondow." Mededeelingen van wege het Nederlandsche Zendings Genootschap (12): 19.

Wheeler, Kayla Renée. 2020. "Conclusion: All Americanists Are Christian,

All Muslims Are Brown, but Some of Us Are Brave." American Religion 2(1): 36. www.jstor.org/stable/10.2979/amerreli.2.1.08 (April 25, 2021).

YPC. 2009. Menapak Sejarah Merapikan Langkah Mempersiapkan Masa Depan.

Bolaang Mongondow: Yayasan Pendidikan Cokroaminoto. 